\title{
PENGARUH STARTER EXPERIMENT APPROACH TERHADAP HASIL BELAJAR FISIKA DI SMA/SMK KELAS X
}

\author{
Karlina Arti Suprapto ${ }^{1, \text { a) }}$ \\ ${ }^{1}$ Prodi Fisika FMIPA UNJ, Jl. Pemuda No. 10, Jakarta 13220 \\ Email: a)karlinasuprapto@gmail.com
}

\begin{abstract}
Abstrak
Penelitian ini bertujuan untuk mengetahui pengaruh Starter Experiment Approach terhadap hasil belajar kognitif siswa di SMA/SMK. Penelitian ini dilaksanakan di SMA Negeri 105 Jakarta. Sampel penelitian ini adalah kelas X MIA A sebagai kelas eksperimen terdiri dari 34 siswa dan X MIA B sebagai kelas kontrol terdiri dari 32 siswa. Instrumen hasil belajar yang digunakan terdiri dari 25 butir soal pilihan ganda. Berdasarkan hasil analisis dan uji-t (uji hipotesis) dengan taraf signifikansi 5\% dan dk $=64$, didapatkan harga $\mathrm{t}_{\text {tabel }}=1.669$ dan $\mathrm{t}_{\text {hitung }}=0.271$ sehingga Ho diterima. Dengan demikian dapat disimpulkan bahwa tidak ada pengaruh yang signifikan antara Starter Experiment Approach terhadap hasil belajar fisika siswa kelas X di SMA/SMK pada materi suhu dan kalor.
\end{abstract}

Kata-kata kunci: Starter Experiment Approach, Hasil Belajar Fisika, Suhu dan Kalor

\begin{abstract}
This study aimed to determine the effect of using the Starter Experiment Approach towards physics cognitive learning outcomes at SMA / SMK. This research will be held at SMA 105 Jakarta. The sample of this study is students in class X MIA A as an experimental class with 34 students and X MIA B as the control class with 32 students. The instrument consists of 25 multiple choice questions. Based on the analysis and t-test (hypothesis test) with a significance level of $5 \%$ and $\mathrm{dk}=64$, obtained table $=1.669$ and $t_{\text {calculate }}=0.271$ so Ho is accepted. The conclusion of this research, there is no significant influence between Starter Experiment Approach towards physics cognitive learning outcomes at SMA / SMK on the material temperature and heat.
\end{abstract}

Keywords: Starter Experiment Approach, Physics Learning Outcomes, Temperature and Heat

\section{PENDAHULUAN}

Pada era global semua negara berkompetisi dalam meningkatkan kualitas pendidikan. Melalui pendidikan kualitas sumber daya manusia dapat ditingkatkan, sehingga tingkat kesejahteraan masyarakat diharapkan dapat meningkat. Lembaga pendidikan, seperti sekolah-sekolah memiliki peran penting dalam menghasilkan sumber daya manusia yang berkualitas, yaitu mampu mengelola sumber daya alam secara efisien dan efektif, memberi layanan jasa yang baik, serta mengembangkan usaha-usaha baru yang dapat meningkatkan kesejahteraan masyarakat. Oleh karena itu, semua lembaga pendidikan berusaha meningkatkan kemampuan lulusannya. 
Upaya yang telah dilakukan pemerintah Republik Indonesia untuk meningkatkan kemampuan lulusannya dengan menyempurnakan kurikulum 2006 atau Kurikulum Tingkat Satuan Pendidikan (KTSP) menjadi kurikulum 2013. Pengembangan kurikulum 2013 merupakan langkah strategis dalam menghadapi globalisasi dan tuntutan masyarakat Indonesia di masa depan. Implementasi Kurikulum 2013 dalam proses pembelajarannya menekankan agar melibatkan peserta didik sebagai aktor utama, peserta didik sebagai subjek belajar dengan kegiatan mengamati, menanya, menganalisis, dan mengkomunikasikan. Sementara untuk penilaian hasil belajar mencakup seluruh aspek kompetensi, yaitu aspek sikap, pengetahuan, dan keterampilan.

Seiring dengan upaya tersebut, beberapa data menyajikan belum tercapainya peningkatan kemampuan lulusan. Berdasarkan data statistik dari hasil The Program for International Student Assessment (PISA) 2012, Indonesia menempati urutan ke-64 dari 65 negara, adapun hasil Science mendapat skor rata-rata 382 dari skor tertinggi 580 (OECD, 2012). Begitupula dengan data Statistik Hasil Akhir untuk mata pelajaran Fisika, pada tahun 2011 mendapat nilai 8.15, namun pada tahun 2012 nilai rata-rata untuk mata pelajaran Fisika yaitu 7.83 (Pusat Penilaian Pendidikan, 2012), terlihat penurunan nilai yang signifikan. Hasil statistik tersebut menunjukkan berkurangnya minat siswa terhadap pembelajaran fisika sehingga masih rendahnya hasil belajar fisika siswa.

Banyak faktor yang mempengaruhi rendahnya hasil belajar fisika siswa, salah satunya adalah cara guru dalam melakukan proses pembelajaran. Penyajian materi fisika sebagian besar masih disajikan sebagai konsep dan kumpulan rumus yang harus dihafalkan, guru lebih dominan sehingga siswa kurang berpartisipasi di dalam kelas (Bestari, 2014:24). Padahal pada prinsipnya, mempelajari Fisika tidak cukup sekedar menghafal suatu konsep, siswa perlu dilibatkan dalam proses pembelajaran. Dengan melibatkan peserta didik, maka mereka akan lebih mudah memahami hasil pembelajarannya.

Saat ini, berbagai inovasi pendekatan pembelajaran berkembang. Dalam membelajarkan suatu materi ajar tertentu harus dipilih penggunaan pendekatan yang paling sesuai dengan tujuan pembelajaran yang akan dicapai karena pendekatan pembelajaran memberikan kerangka dan arahan bagi guru. Pemilihan pendekatan pembelajaran merupakan suatu komponen penting untuk guru merencanakan, melaksanakan, dan mengevaluasi pembelajaran. Pada dasarnya, pendidikan fisika di Sekolah Menengah Umum menekankan pada pemberian pengalaman secara langsung kepada siswa tentang fakta, konsep, prinsip, dan proses penemuan. Dengan penekanan pembelajaran seperti itu, maka diharapkan guru dapat memilih jenis pendekatan pembelajaran yang sesuai agar hal tersebut dapat terealisasikan sehingga hasil belajar siswa dapat meningkat. Dari pemaparan tersebut, maka dibutuhkan suatu pendekatan dalam pembelajaran agar siswa dapat dengan mudah memahami materi pembelajaran.

Menurut Memes (Bestari, 2014:24), salah satu pendekatan komprehensif untuk pembelajaran Fisika adalah Starter Experiment Approach (SEA). Starter Experiment Approach (SEA) atau biasa dikenal dengan Pendekatan Starter Eksperimen (PSE) yang mempunyai ciri khusus yaitu mengetengahkan alam lingkungan sebagai penyulut (starter). Pembelajaran SEA ini dilakukan dengan mempraktikkan prinsip-prinsip metode ilmiah meliputi pengamatan, dugaan, desain percobaan, eksperimen dan laporan hasil penelitian (Hermanto, 2011:25). Kegiatan SEA sebagian besar dipusatkan pada keaktifan dan keterampilan proses siswa. Keterampilan proses tersebut berorientasi kepada proses bagaimana siswa dapat menemukan konsep-konsep IPA yang sedang dipelajari. Guru berperan sebagai fasilitator, sementara siswa sebagai pelaku dalam setiap langkah pembelajaran. Dengan pendekatan ini tentunya diharapkan dapat meningkatkan hasil belajar sains siswa.

Terdapat beberapa penelitian terkait dua pendekatan di atas. Salah satunya penelitian yang dilakukan oleh Ni Luh Pt. Yuliana Dewi (2014) yang berjudul "Pengaruh Pendekatan Starter Eksperimen (PSE) berbasis Reinforcement terhadap Hasil Belajar IPA Kelas V Sekolah Dasar Gugus Letda Kajeng Kecamatan Denpasar Utara” menyimpulkan bahwa Pendekatan Starter Eksperimen (PSE) berbasis Reinforcement berpengaruh terhadap hasil belajar IPA siswa di kelas V di Sekolah Gugus Letda Kajeng Tahun Ajaran 2013/2014. Penelitian lainnya yaitu oleh I Dewa Putu Subamia (2012) yang berjudul "Keterampilan Proses Sains dan Hasil Belajar Siswa pada Pembelajaran menggunakan Pendekatan Starter Experiment" menyatakan bahwa hasil belajar pada pembelajaran sains siswa yang dibelajarkan dengan model pembelajaran menggunakan PSE lebih tinggi dibandingkan dengan yang dibelajarkan dengan model PL 
Berdasarkan teori dasar dan hasil penelitian sebelumnya, maka perlu dilakukan penelitian mengenai "Pengaruh Starter Experiment Approach terhadap Hasil Belajar Fisika Siswa di SMA/SMK Kelas X.”

\section{METODE PENELITIAN}

Metode penelitian yang digunakan dalam penelitian ini adalah metode penelitian quasi eksperimen (quasi experimental method). Di dalam metode quasi eksperimen terdapat perlakuan (treatment). Dengan demikian metode penelitian eksperimen dapat diartikan sebagai metode penelitian yang digunakan untuk mencari pengaruh perlakuan tertentu terhadap yang lain atau dengan kata lain metode eksperimen adalah suatu cara yang digunakan dalam penelitian untuk melihat hubungan sebab-akibat antara dua atau lebih variabel, di mana salah satu variabel adalah variabel kontrol.

Penelitian ini menggunakan dua sampel kelas. Masing-masing kelas mendapatkan perlakuan yang berbeda. Sampel pada kelas eksperimen diberikan perlakuan dengan menggunakan pembelajaran dengan Starter Experiment Approach. Sampel pada kelas kontrol diberikan perlakuan sesuai dengan kurikulum 2013.

Desain yang digunakan dalam penelitian quasi eksperimen ini adalah Posttest Control Group Design. Untuk mengetahui keadaan awal kelompok eksperimen dan kontrol, digunakan nilai siswa pada materi sebelumnya.

TABEL 1. Desain Penelitian

\begin{tabular}{ccc}
\hline Kelas & Perlakuan & Posttest \\
\hline Eksperimen & $\mathrm{X}_{1}$ & $\mathrm{O}_{2}$ \\
Kontrol & $\mathrm{X}_{2}$ & $\mathrm{O}_{2}$ \\
\hline \multicolumn{3}{c}{ Keterangan: } \\
\multicolumn{3}{c}{$\mathrm{O}_{2}$ : Nilai tes akhir (setelah perlakuan) } \\
$\mathrm{X}_{1}$ : Pembelajaran Starter Experiment Approach \\
$\mathrm{X}_{2}$ : Pembelajaran sesuai dengan kurikulum 2013
\end{tabular}

\section{HASIL DAN PEMBAHASAN}

\section{Hasil Penelitian}

\section{Deskripsi Data}

Dalam penelitian ini data yang diambil adalah data hasil belajar fisika siswa yang berupa kemampuan kognitif pada kelas kontrol yang diberikan perlakuan sesuai dengan kurikulum 2013 dan kelas eksperimen yang diberikan perlakuan Starter Experiment Approach pada pokok bahasan suhu dan kalor. Soal berbentuk pilihan ganda berjumlah 25 soal dengan 5 alternatif jawaban. Rentangan nilai yang digunakan adalah 0 sampai dengan 100. Data selengkapnya mengenai hasil belajar kedua kelas siswa tersebut akan diuraikan sebagai berikut:

TABEL 2. Statistik Deskriptif Hasil Belajar Siswa Kelas Kontrol dan Eksperimen

\begin{tabular}{lcc}
\hline Statistik & Kelas Kontrol & Kelas Eksperimen \\
\hline n (Banyak Siswa) & 32 & 34 \\
Skor Maksimum & 88 & 88 \\
Skor Minimum & 40 & 28 \\
Rentang nilai & 8 & 10 \\
Rata-rata & 63,778 & 65,222 \\
\hline
\end{tabular}



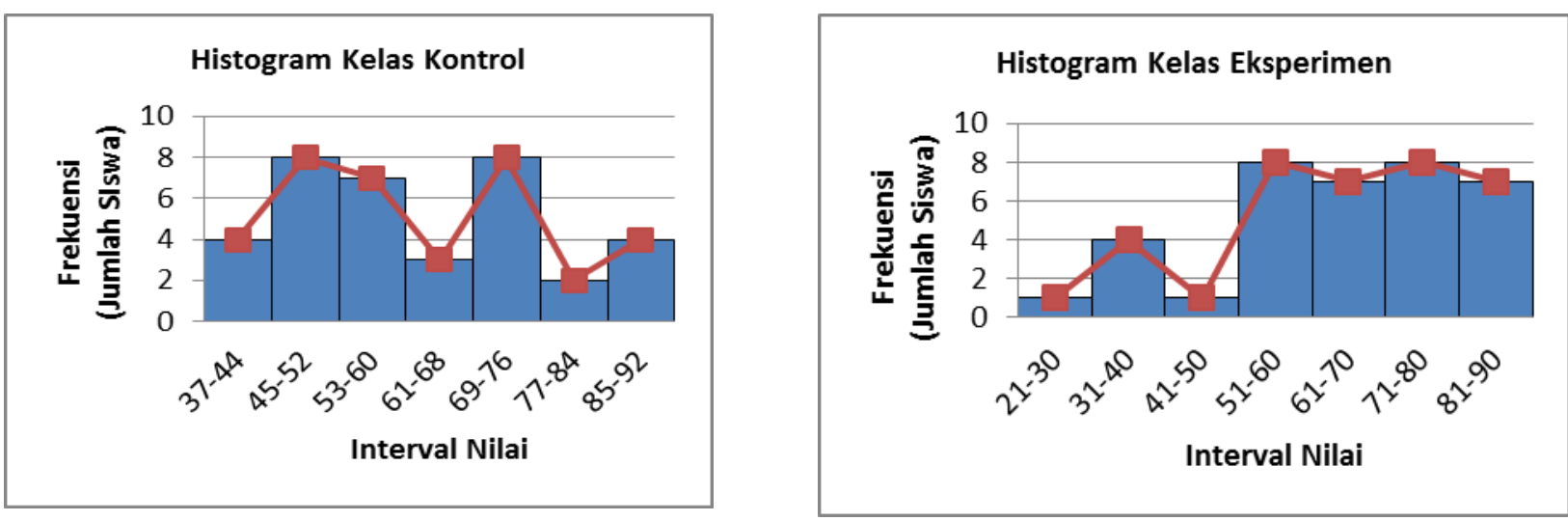

GRAFIK 1. Histogram Hasil Belajar Kognitif Siswa Kelas Kontrol. GRAFIK 2. Histogram Hasil Belajar Kognitif Siswa Kelas Eksperimen.

Berdasarkan tabel dapat dilihat bahwa kelas kontrol yang memperoleh nilai di atas rata-rata sebanyak $47 \%$ dan siswa yang memperoleh nilai dibawah rata-rata sebesar 53\%. Sementara, pada kelas eksperimen yang memperoleh nilai di atas rata-rata sebanyak $47 \%$ dan siswa yang memperoleh nilai dibawah rata-rata sebesar 53\%. Selanjutnya, setelah didapatkan data hasil belajar siswa, maka dapat diperoleh data kemampuan kognitif dari masing-masing kelas. Data selengkapnya mengenai aspek kognitif kedua kelas akan diuraikan sebagai berikut:

TABEL 3. Statisitik Deskriptif Rata-rata Tingkat Kognitif Siswa Kelas Kontrol dan Eksperimen

\begin{tabular}{ccc} 
Aspek & \multicolumn{2}{c}{$\begin{array}{c}\text { Rata-rata siswa yang } \\
\text { menjawab benar }\end{array}$} \\
\cline { 2 - 3 } & Kontrol & Eksperimen \\
\hline C1 & 31,33 & 32,33 \\
C2 & 25,833 & 27 \\
C3 & 22,667 & 24,667 \\
C4 & 13,857 & 16,286 \\
C5 & 11 & 13 \\
C6 & 11 & 9 \\
\hline
\end{tabular}

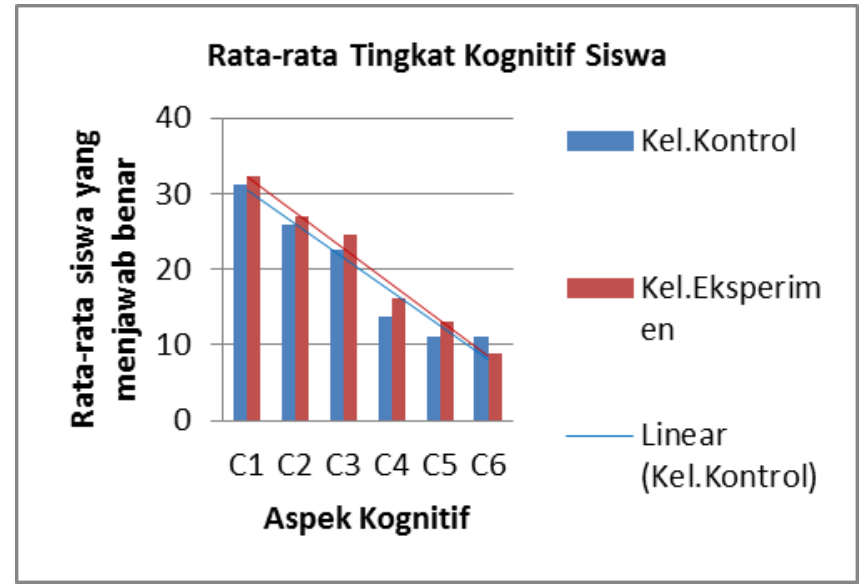

GRAFIK 3. Diagram batang Rata-rata Tingkat Kognitif Siswa Kelas Kontrol dan Eksperimen 
Berdasarkan diagram batang di atas diperoleh hasil bahwa kemampuan siswa pada tiap ranah kognitif berfluktuasi baik dalam kelas kontrol dan eksperimen.

\section{Pengujian Prasyarat Analisis}

\section{Uji Normalitas}

Uji normalitas dilakukan dengan menggunakan Uji Chi-Kuadrat. Dari pengujian hasil belajar kelas kontrol (Kelas yang diberikan perlakuan sesuai kurikulum 2013) diperoleh harga $\chi^{2}$ hitung $=8,126$ dan $\chi_{\text {tabel }}^{2}=12,592$ pada taraf signifikan $\alpha=0,05$ dan $\mathrm{dk}=6$.

Dari pengujian pada kelas eksperimen (Kelas yang diberikan perlakuan Starter Experiment Approach) diperoleh harga $\chi^{2}$ hitung $=7,197$ dan $\chi_{\text {tabel }}^{2}=12,592$ pada taraf signifikan $\alpha=0,05 \mathrm{dan} \mathrm{dk}$ $=6$.

Karena harga $\chi^{2}$ hitung yang diperoleh kedua kelas lebih kecil dari harga $\chi^{2}$ tabel, maka dapat disimpulkan bahwa kedua kelas berasal dari populasi yang berdistribusi normal.

\section{Uji Homogenitas}

Uji homogenitas dilakukan dengan menggunakan Uji F. Dari pengujian diperoleh $F_{\text {hitung }}=1,361$ dan $F_{\text {tabel }}$ berada di antara 1,78 dan 1,72 pada taraf signifikan $\alpha=0,05$. Karena harga $F_{\text {hitung }}$ yang diperoleh lebih kecil dari harga $\mathrm{F}_{\text {tabel, }}$ maka dapat disimpulkan bahwa data hasil belajar kedua kelas sampel berasal dari kelas yang homogen.

\section{Uji Hipotesis}

Dari data penelitian didapat rata-rata hasil belajar siswa pada kelas kontrol sebesar 64,375, varian 233,661, dan simpangan baku gabungan 15,528, sedangkan rata-rata hasil belajar siswa pada kelas eksperimen sebesar 65,412, varian 248,128, dan simpangan baku gabungan 15,528. Dari hasil perhitungan diperoleh nilai thitung sebesar 0,271. Dengan taraf signifikan $\alpha=0,05 \mathrm{dan} \mathrm{dk}=64$ maka $t_{\text {tabel }}$ sebesar 1,669.

\section{Pembahasn}

Karena $t_{\text {hitung }}<\mathrm{t}_{\text {tabel, }}$, maka terima $\mathrm{H}_{0}$ dan tolak $\mathrm{H}_{1}$. Hal ini berarti hasil belajar fisika siswa yang diajar dengan menggunakan Starter Experiment Approach tidak memiliki pengaruh yang signifikan.

Sebelum dilakukan penelitian, peneliti sebelumnya menyusun instrumen pembelajaran terlebih dahulu, ada pun instrumen yang digunakan adalah Rencana Pelaksanaan Pembelajaran (RPP) untuk kelas kontrol dan eksperimen untuk materi suhu dan kalor, serta menyusun soal tes uji coba yang berjumlah 50 butir soal. Soal tes uji coba diujikan kepada kelas X MIA 2 dan X MIA 3 di SMA Negeri 98 Jakarta. Soal uji coba diujikan terlebih dahulu untuk mengetahui kualitas soal yang akan digunakan untuk mengelola aspek kognitif siswa yang diteliti. Instrumen yang digunakan sebanyak 25 soal pilihan ganda dengan lima alternatif jawaban. RPP, soal uji coba, dan hasil uji coba soal dapat dilihat pada lampiran.

Peneliti melakukan penelitian di SMA Negeri 105 Jakarta, kelas yang akan diteliti yakni kelas X MIA A sebagai kelas eksperimen dan kelas X MIA B sebagai kelas kontrol. Pada saat penelitian, kelas kontrol diberikan perlakuan sesuai dengan kurikulum 2013, yakni menggunakan Scientific Approach untuk pembelajarannya. Langkah pembelajaran dengan Scientific Approach meliputi langkah mengamati, menanya, menalar atau eksperimen, mengasosiasi, mengkomunikasikan. Pada langkah pertama, siswa mengamati, kemudian siswa bertanya, namun karena masih pasifnya siswa, guru terlebih dahulu memberikan pertanyaan untuk memotivasi siswa bertanya, setelah dilakukan proses mengamati dan menanya, selanjutnya siswa yang sudah duduk berkelompok melakukan langkah menalar atau eksperimen, selanjutnya siswa mengasosiasi terkait hasil percobaan yang akan dibandingkan dengan teori yang sudah ada. Setelah siswa berdiskusi, salah satu kelompok 
mengkomunikasikan hasil diskusi mereka, sementara kelompok siswa yang lain menyimak penjabaran dari kelas yang akan mengkomunikasikan hasil diskusi tersebut.

Kelas eksperimen menggunakan Starter Experiment Approach dalam proses pembelajarannya. Langkah pembelajaran dengan Starter Experiment Approach (SEA) meliputi percobaan awal (starter experiment), pengamatan (observasi), rumusan masalah, dugaan sementara, percobaan pengujian, penyusunan konsep, mencatat pelajaran, dan penerapan konsep. Pada langkah pertama, siswa melakukan percobaan awal yang kebanyakan berkaitan dengan lingkungan sekitar walaupun hanya sebatas dalam video, hal ini dilakukan karena ciri dari Starter Experiment Approach yaitu lingkungan sebagai penyulut pembelajaran, kemudian guru menanyakan beberapa pertanyaan untuk membimbing siswa melakukan pengamatan, rumusan masalah, dan dugaan percobaan, selanjutnya siswa melakukan langkah percobaan pengujian untuk membuktikan dugaan sementara yang telah mereka rumuskan. Pada langkah penyusunan konsep, di sini guru menyempurnakan konsep yang telah didapatkan oleh siswa, selanjutnya siswa diharuskan mencatat pelajaran, setelah siswa mendapatkan materi, guru memberikan penerapan konsep berupa soal untuk mengetahui sejauh mana materi telah diserap oleh siswa.

Setelah hasil post test didapatkan, dilakukan pengolahan untuk mengetahui hasil belajar fisika di masing-masing kelas eksperimen. Berdasarkan diagram batang pada grafik 3, dapat dilihat bahwa kelas eksperimen memiliki rata-rata tingkat kognitif yang berfluktuasi baik, berbeda dengan kelas kontrol, pada aspek sintesis dan evaluasi rata-rata tingkat kognitif siswa cenderung sama, ini berarti siswa pada kelas ini memiliki nilai kreativitas, afektif, dan psikomotorik yang sebanding. Jika diperhatikan pada aspek C1 sampai C5, siswa pada kelas eksperimen selalu lebih unggul dari kelas kontrol, tetapi pada aspek C6 siswa pada kelas kontrol lebih unggul dari siswa kelas eksperimen, hal ini dapat menunjukkan bahwa siswa pada kelas eksperimen memiliki kemampuan kognitif yang lebih unggul dari siswa kelas kontrol, namun, untuk kemampuan afektif dan psikomotorik, siswa kelas kontrol lebih unggul dari siswa kelas eksperimen, hal ini sesuai dengan daftar nilai yang peneliti miliki. Kemudian, untuk memperkuat hasil penelitian dilakukan pengujian hipotesis melalui perhitungan analisis statistik. Pengujian hipotesis menggunakan uji t. Analisis statistik parametrik uji t dapat diterapkan apabila data yang dihasilkan berdistribusi normal dan homogen. Oleh sebab itu, sebelumnya dilakukan 2 uji prasyarat, yaitu: uji normalitas dan uji homogenitas. Uji Chi-Kuadrat digunakan untuk menentukan normalitas, sementara uji F digunakan untuk menentukan homogenitas. Berdasarkan perhitungan, diketahui bahwa sampel berdistribusi normal dan homogen.

Selanjutnya, hasil uji hipotesis menggunakan uji t, diketahui bahwa $\mathrm{H}_{\mathrm{o}}$ diterima, yang berarti bahwa hasil belajar fisika siswa yang diajar dengan menggunakan Starter Experiment Approach sama dengan atau kurang dari dari hasil belajar fisika siswa kelas kontrol. Hal ini dapat disebabkan oleh:

- Langkah pembelajaran pada kelas eksperimen yaitu percobaan awal, pengamatan, rumusan masalah, dugaan sementara, percobaan pengujian, penyusunan konsep, mencatat pelajaran, dan penerapan konsep, sementara langkah pembelajaran pada kelas kontrol yaitu mengamati, menanya, menalar atau eksperimen, mengasosiasi, mengkomunikasikan. Berdasarkan hasil telaah peneliti, langkah pembelajaran yang dapat menyebabkan lebih tingginya hasil belajar kognitif fisika siswa pada kelas eksperimen yaitu penyusunan konsep, mencatat pelajaran, dan penerapan konsep. Pada langkah penyusunan konsep, di sini guru benar-benar dituntut untuk membantu siswa untuk menyempurnakan konsep yang mereka dapatkan, jadi siswa benar-benar dibantu untuk mendapatkan konsep yang benar, sementara pada langkah pembelajaran kelas kontrol, guru tidak dituntut untuk menyempurnakan konsep. Selanjutnya, pada langkah pembelajaran mencatat pelajaran pada kelas eksperimen, di langkah ini, siswa pun dituntut untuk mencatat pelajaran yang diberikan oleh guru, dengan mencatat pelajaran tentu dapat menjadi landasan siswa untuk mengingat pembelajaran yang telah diberikan, berbeda dengan kelas kontrol, pada kelas kontrol tidak disebutkan untuk siswa mencatat pelajaran, jadi ini tergantung pada inisiatif dan motivasi siswa untuk mencatat. Pada praktiknya, beberapa siswa dengan inisiatif mencatat pelajaran yang diberikan, namun sebagian besar siswa tidak mencatat pelajaran yang telah diberikan, tentu ini menjadi salah satu faktor rendahnya hasil belajar kognitif siswa. Langkah selanjutnya yang dapat memperlihatkan lebih tingginya hasil belajar fisika pada kelas eksperimen yaitu penerapan 
konsep. Penerapan konsep merupakan salah satu bentuk evaluasi dari keberhasilan proses pembelajaran, siswa akan melakukan evaluasi setiap mendapatkan materi pembelajaran (setiap pertemuan), hal ini tentu membantu siswa lebih terlatih untuk mengerjakan soal, sehingga siswa lebih siap untuk mengerjakan post test yang akan diberikan, lain halnya dengan pembelajaran kelas kontrol, siswa tidak dituntut untuk mengevaluasi materi yang telah mereka dapatkan, jadi guru tidak dapat mengukur sejauh mana siswa dapat menyerap materi yang telah diajarkan oleh guru. Langkah pembelajaran penyusunan konsep, mencatat pelajaran, dan penerapan konsep pada kelas eksperimen memang harus dilakukan, karena langkah pembelajaran tersebut merupakan rangkaian langkah pembelajaran pada kelas eksperimen.

- Meskipun Ho diterima, namun untuk nilai kognitif pada kelas kontrol memiliki nilai yang lebih rendah dibandingkan dengan kelas eksperimen, namun untuk nilai psikomotorik dan afektif, kelas yang menggunakan Scientific Approach memiliki nilai yang lebih tinggi dibandingkan dengan kelas yang menggunakan Starter Experiment Approach. Siswa pun terlihat lebih kretaif dan berani untuk mengemukakan ide mereka, hal ini dikarenakan siswa sudah terbiasa untuk mengkomunikasikan ide-ide yang mereka miliki. Lebih unggulnya nilai afektif dan psikomotorik pun sesuai dengan diagram batang pada grafik 3.

\section{SIMPULAN}

Berdasarkan hasil penelitian didapatkan data bahwa tidak ada pengaruh yang signifikan antara Starter Experiment Approach terhadap hasil belajar fisika siswa kelas X di SMA/SMK pada materi suhu dan kalor.

\section{UCAPAN TERIMAKASIH}

Terimakasih kepada pihak-pihak yang jurnal dan bukunya telah membantu saya dalam menyelesaikan makalah ini, kepada penyelenggara seminar, kepada orang tua saya yang selalu medukung kegiatan positif saya, kepada adik dan kakak saya yang selalu memberikan semangat, serta kepada teman-teman yang tidak dapat saya sebutkan satu per satu.

\section{REFERENSI}

[1] D. Bestari, "Pembelajaran Fisika menggunakan SEA berbantuan Games untuk Mengembangkan Karakter Siswa SMP”, Unnes Physics Education Journal, pp. 24-29, 2014.

[2] D. L. Ni, "Pengaruh Pendekatan Starter Eksperimen (PSE) Berbasis Reinforcement terhadap Hasil Belajar IPA Kelas V Sekolah Dasar Gugus Letda Kajeng Kecamatan Denpasar Utara”. E-Journal Mimbar PGSD Universitas Pendidikan Ganesha Jurusan PGSD. Vol:2, 2014.

[3] H. Dody, "Kajian Kemampuan Berpikir Kritis dan Peningkatan Prestasi Belajar Siswa SMP dalam Pembelajaran Fisika dengan Pendekatan Starter Ekpserimen (PSE)”, Skripsi Jurusan Pendidikan Fisika Universitas Pendidikan Indonesia, 2011.

[4] E. Kosasih, Strategi Belajar dan Pembelajaran Implementasi Kurikulum 2013, Bandung: Yrama Widya, 2014.

[5] D. R. Mitra, “Analisis Keterampilan Berpikir Kritis Siswa Pada Pembelajaran Fisika dengan Pendekatan Starter Eksperimen”, Jurnal Universitas Muhammadiyah Purworejo Radiasi, vol. 5 no. 1, pp. 73-76, 2014.

[6] S, Abdullah, Pembelajaran Saintifik untuk Implementasi Kurikulum 2013, Jakarta: Bumi Aksara, 2014. 
[7] P. T. I Dewa, "Keterampilan Proses Sains dan Hasil Belajar Siswa pada Pembelajaran Menggunakan Pendekatan Starter Experiment”, Jurnal Pendidikan dan Pengajaran, vol. 45 No. 1, pp. 27-37, 2012. 